\title{
EFEKTIVITAS SISTEM INFORMASI KAMPUS (SISFOKAMPUS) SEBAGAI ENTERPRISE RESOURCE PLANNING (ERP) UPAYA PENINGKATAN KINERJA KARYAWAN DI UNIVERSITAS ISLAM MALANG
}

\author{
Dewi Muftin Nabiilah \\ Mahasiswa Magister Manajemen Pascasarjana Universitas Islam Malang \\ Email : muftinnabiilah@gmail.com
}

\begin{abstract}
Abstrak
Penelitian ini didasarkan pada masalah pokok yaitu efektivitas Sisfokampus upaya peningkatan kinerja karyawan. Sistem Informasi Manajemen (SIM) terjadi di kampus adalah sistem pengelolaan akademik terpadu yang yang memiliki beberapa sub bagian tertentu saling terintegrasi dan terkait yang tujuannya agar mempermudah pekerjaan karyawan di Universitas Islam Malang. Beberapa masalah terkait efektivitas Sisfokampus yang selama ini terjadi antara lain yang berkaitan dengan kualitas sistem, kualitas informasi, penggunaan dan juga kepuasan pemakai. Tujuan Penelitian ini adalah untuk mengetahui pengaruh efektivitas Sisfokampus yang ditentukan oleh faktor-faktor Sistem Informasi Manajemen (SIM) upaya peningkatan kinerja karyawan di Universitas Islam Malang.

Obyek penelitian ini adalah karyawan Universitas Islam Malang yang pekerjaannya menggunakan Sisfokampus. Penelitian ini menggunakan analisis kuantitatif melalui penggunaan Analisis Regresi Linier Berganda yang dimaksudkan untuk mengetahui besaran pengaruh variabel efektivitas SIM/Sisfokampus terhadap peningkatan kinerja karyawan secara simultan dan parsial.

Hasil penelitian menunjukkan bahwa secara simultan, efektivitas SIM/Sisfokampus $(X)$ berpengaruh secara signifikan terhadap peningkatan kinerja karyawan (Y). Sedangkan, secara parsial, efektivitas Sisfokampus yang terdiri dari empat faktor Sistem Informasi Manajemen (SIM) yang meliputi: kualitas sistem (X1) berpengaruh positif terhadap peningkatan kinerja karyawan (Y) sebesar $7.49 \%$, kualitas informasi $(\mathrm{X} 2)$ berpengaruh positif terhadap peningkatan kinerja karyawan $(Y)$ sebesar 3.19\%, penggunaan (X3) berpengaruh positif terhadap peningkatan kinerja karyawan $(Y)$ sebesar $1.38 \%$ dan kepuasan pemakai $(X 4)$ berpengaruh positif terhadap peningkatan kinerja karyawan $(\mathrm{Y})$ sebesar $5.77 \%$. Dari ke empat faktor Sistem Informasi Manajemen yang memberikan pengaruh dominan secara parsial terhadap peningkatan kinerja karyawan, yaitu faktor kualitas sistem (X1) berpengaruh positif terhadap peningkatan kinerja karyawan (Y) sebesar 7.49\%.

Selanjutnya penelitian ini dapat disimpulkan bahwa efektivitas Sistem Informasi Manajemen (SIM)/Sisfokampus berpengaruh positif terhadap peningkatan kinerja karyawan di Universitas Islam Malang. Bahwa secara menyeluruh efektivitas Sistem Informasi Manajemen (SIM)/Sisfokampus telah dilaksanakan dan dijalankan sesuai dengan ukuran kinerja karyawan.
\end{abstract}

Kata kunci : Kesadaran Merek, Persepsi Kualitas, Kepercayaan Merek, Keputusan Membeli 


\begin{abstract}
This research is based on the main problem is the effectiveness of Sisfokampus efforts to improve employee performance. Management Information System (MIS) takes place on campus is an integrated academic management system which has several sub-sections that are integrated and related to the purpose to facilitate the work of employees at the Islamic University of Malang. Some problems related to the effectiveness of Sisfokampus which has been happening among others related to system quality, information quality, usage and also user satisfaction. The purpose of this study is to determine the effect of effectiveness of Sisfokampus which is determined by the factors of Management Information System (SIM) and also the constraints of the effort to improve employee performance in Islamic University of Malang.

The object of this research is employees of Islamic University of Malang whose job is using Sisfokampus. This study uses quantitative analysis through the use of Multiple Linear Regression Analysis which is intended to know the magnitude of the effect of effectiveness of SIM / Sisfokampus variable to simultaneous and partial employee performance improvement.

The results showed that simultaneously, the effectiveness of SIM / Sisfokampus $(X)$ had significant effect to the improvement of employee performance $(\mathrm{Y})$. Meanwhile, partially, the effectiveness of Sisfokampus consisting of four factors of Management Information System (SIM) which include: system quality $(\mathrm{X} 1)$ has a positive effect on employee performance improvement $(\mathrm{Y})$ of $7.49 \%$, the quality of information (X2) has a positive effect on employee performance improvement $(Y)$ equal to $3.19 \%$, the use $(X 3)$ has a positive effect on employee performance improvement $(Y)$ of $1.38 \%$ and user satisfaction (X4) has a positive effect on employee performance improvement (Y) of 5.77\%. From the four factors of Management Information System which give partially dominant influence to the improvement of employee performance, that is system quality factor (X1) have positive effect to the improvement of employee performance (Y) equal to $7.49 \%$.
\end{abstract}

Furthermore, this research can be concluded that the effectiveness of Management Information System (MIS) / Sisfokampus have a positive effect on employee performance improvement in Islamic University of Malang. That the overall effectiveness of Management Information System (MIS) / Sisfokampus has been implemented and executed in accordance with the employee performance measure.

Keyword : Effectiveness, Management Information System, employee performance

\title{
PENDAHULUAN
}

Penelitian ini didasarkan pada masalah pokok yaitu efektivitas Sisfokampus upaya peningkatan kinerja karyawan. Sistem Informasi Manajemen (SIM) terjadi di kampus adalah sistem pengelolaan akademik terpadu yang yang memiliki beberapa sub bagian tertentu saling terintegrasi dan terkait yang tujuannya agar mempermudah pekerjaan karyawan di Universitas Islam Malang. Beberapa masalah terkait efektivitas Sisfokampus yang selama ini terjadi antara lain yang berkaitan dengan kualitas sistem, kualitas informasi, penggunaan dan juga kepuasan pemakai. Tujuan Penelitian ini adalah untuk mengetahui pengaruh efektivitas Sisfokampus yang ditentukan oleh faktor-faktor Sistem Informasi 
Manajemen (SIM) upaya peningkatan kinerja karyawan di Universitas Islam Malang.

Berdasarkan uraian latar belakang yang telah diuraikan diatas, maka dapat dirumuskan permasalahan yaitu Berapa besar pengaruh efektifitas Sistem Informasi Kampus (Sisfokampus) terhadap kinerja karyawan di Universitas Islam Malang dan berapa besar pengaruh efektifitas Sistem Informasi Kampus (Sisfokampus) yang ditentukan oleh faktor-faktor Sistem Informasi Manajemen yang meliputi kualitas sistem, kualitas informasi, penggunaan dan kepuasan pemakai pada karyawan di Universitas Islam Malang. Beberapa manfaat yang diidentifikasi menjadi tujuan dalam penelitian ini adalah untuk mengetahui seberapa besar pengaruh efektifitas Sistem Informasi Kampus (Sisfokampus) dan pengaruh Sisfokampus yang ditentukan oleh faktor-faktor Sistem Informasi Manajemen yang meliputi kualitas sistem, kualitas informasi, penggunaan dan kepuasan pemakai dalam upaya peningkatan kinerja karyawan.

\section{KAJIAN TEORI}

Efektifitas merupakan suatu ukuran yang memberikan gambaran seberapa jauh target dapat tercapai, baik secara kualitas maupun waktu, orientasinya adalah keluaran (output) yang dihasilkan (Ni Putu, 2015). Umumnya efektifitas sering dihubungkan dengan efisiensi dalam emncapai tujuan perusahaan, tujuan atau sasaran yang telah tercapai sesuai dengan rencana dapat dikatakan efektif, tetapi belum tentu efisien. (Sedarmayanti, 2001) mengatakan bahwa efektifitas merupakan suatu ukuran yang memberikan gamabran seberapa jauh target dapat tercapai. Efektifitas adalah pemanfaatan sumber daya, sarana dan prasarana dalam jumlah tertentu yang secara sadar ditetapkan sebelumnya untuk menghasilkan sejumlah barang atas jasa kegiatan yang dijalankannya.

Sistem Informasi Manajemen (SIM) terjadi di kampus adalah merupakan sistem pengelolaan manajemen akademik yang saat ini diterapkan hampir pada semua Universitas termasuk Universitas Islam Malang. Sistem Informasi Manajemen yang diterapkan di Universitas Islam Malang merupakan sistem informasi yang terpadu dan memiliki beberapa sub yaitu Sistem Informasi Akademik, Sistem Informasi Keuangan, Sistem Informasi Kepegawaian dan Sistem Informasi Kemahasiswaan. Sub sistem tersebut terintegrasi dan saling terkait sehingga menjadi sistem informasi manajemen yang terpadu. Dengan adanya fasilitas sistem informasi manajemen terpadu tersebut diharapkan semua proses akademik dan non akademik dapat berjalan dengan lebih mudah dan lebih cepat baik bagi mahasiswa, karyawan, dosen maupun pihak lainnya yang terkait.

\section{METODE PENELITIAN}

Jenis penelitian yang digunakan dalam penelitian ini adalah penelitian kuantitatif.Menurut Sugiyono (2009), "Penelitian kuantitaif adalah metode penelitian yang berlandasan pada aliran positivism.Aliran positivism, dimana dalam memandang gejala, lebih bersifat tunggal, statis, dan kongkrit". Menurut Sugiyono (2009), "Dalam penelitian kuantitatif, peneliti menggunakan instrument untuk mengumpulkan data atau 
mengukur status variabel yang diteliti". Jadi dalam penelitian kuantitatif melakukan analisis data untuk menguji hipotesis.

Lokasi penelitian dilakukan di Universitas Islam Malang. Waktu penelitian yaitu diawali dengan pengalaman banyaknya permasalahan yang dirasa peneliti selama penerimaan mahasiswa baru tahun akademik 2017-2018, selain itu ada beberapa permasalahan sepanjang tahun akademik 2017-2018 berjalan. Dan peneliti mulai penelitian dimulai pada bulan Februari sampai Mei 2018.

Penelitian ini meliputi dua variabel, yaitu Efektifitas Sistem Informasi Manajemen yang di penelitian ini adalah Sisfokampus sebagai variabel bebas (X) yang meliputi empat faktor, yaitu : faktor kualitas sistem, faktor kualitas informasi, faktor penggunaan dan faktor kepuasan pemakai. Adapun kinerja karyawan sebagai variabel terikat $(\mathrm{Y})$.

Metode pengumpulan data dilakukan melalui penyebaran kuesioner atau daftar pertanyaan atau seperangkat pertanyaan tertulis yang disusun oleh peneliti yang berisikan pertanyaan tentang variabel-variabel yang diteliti.

Dalam penelitian ini, teknik yang digunakan adalah teknik analisis regresi berganda, hal ini dikarenakan variabel bebas dalam penelitian ini lebih dari satu. Teknik analisis regresi berganda merupakan teknik uji yang digunakan untuk mengetahui pengaruh variabel dependen terhadap variabel independen. Ada beberapa Uji yang dilakukan dalam penelitian ini, yaitu uji validitas dan reliabilitas, uji asumsi klasik, dan uji kelayakan model.

\section{HASIL ANALISIS DATA}

Gambaran mengenai Sistem Informasi Manajemen yang disini adalah Sistem Informasi Kampus (Sisfokampus) tercermin dari hasil jawaban responden yang diukur melalui empat faktor, sebagaimana telah ditetapkan dalam kerangka berfikir yang dikemukakan di muka. Selanjutnya dilakukan analisis dengan menggunakan analisis regresi linier berganda yang berguna untuk mendapatkan pengaruh variabel-variabel bebas $X_{1}$ (kualitas system), $X_{2}$ (kualitas informasi), $X_{3}$ (penggunaan), dan $X_{4}$ (kepuasan pemakai) terhadap variabel $Y$ (kinerja karyawam). Dalam pengolahan data dengan menggunakan analisis regresi linier berganda, dilakukan beberapa tahapan untuk mencari pengaruh antara variabel independen terhadap dependen. Berdasarkan hasil pengolahan data dengan menggunakan software SPSS 18. 
Tabel Hasil Analisis Regresi Linier Berganda

\begin{tabular}{|c|c|c|c|c|}
\hline Variabel & $B$ & $t_{\text {hitung }}$ & Signifikan & Keterangan \\
\hline Konstanta & 11.423 & & & \\
\hline X1 (Kualitas sistem) & 0.101 & 0.322 & 0.749 & $\begin{array}{c}\text { Tidak } \\
\text { signifikan }\end{array}$ \\
\hline $\begin{array}{l}\text { X2 (Kualitas } \\
\text { informasi) }\end{array}$ & 0.257 & 1.008 & 0.319 & $\begin{array}{c}\text { Tidak } \\
\text { signifikan }\end{array}$ \\
\hline X3 (Penggunaan) & 0.249 & 1.509 & 0.138 & $\begin{array}{c}\text { Tidak } \\
\text { signifikan }\end{array}$ \\
\hline $\begin{array}{l}\text { X4 (Kepuasan } \\
\text { pemakai) }\end{array}$ & 0.129 & 0.562 & 0.577 & $\begin{array}{c}\text { Tidak } \\
\text { signifikan }\end{array}$ \\
\hline A & & & $=0.050$ & \\
\hline $\begin{array}{l}\text { Koefisien } \\
\text { Determinasi }\left(R^{2}\right)\end{array}$ & & & $=0.278$ & \\
\hline F-hitung & & & $=4.528$ & \\
\hline F-tabel $\left(F_{4,47,0.05}\right)$ & & & $=2.570$ & \\
\hline Signifikansi $F$ & & & $=0.004$ & \\
\hline t-tabel $\left(t_{47,0.05}\right)$ & & & $=2.012$ & \\
\hline
\end{tabular}

Sumber : Output Hasil Analisis SPSS

Berdasarkan tabel di atas, diperoleh model regresi sebagai berikut : $Y=11.423+0.101 X_{1}+0.257 X_{2}+0.249 X_{3}+0.129 X_{4}+e_{i}$

Pengujian secara simultan dilakukan untuk menunjukkan apakah semua variabel bebas yang digunakan dalam model regresi memiliki pengaruh yang signifikan terhadap variabel $Y$ (kinerja karyawan). Semua variabel tersebut di uji serentak dengan menggunakan uji $F$.

Berdasarkan di atas, dapat dilihat bahwa diperoleh nilai $F_{\text {hitung }}$ lebih besar dari $F_{\text {tabel }}$ dan memiliki nilai signifikansi yang lebih kecil dari $\alpha(0.05)$, sehingga $\mathrm{H}_{0}$ ditolak. Artinya bahwa secara simultan/serentak, variabel bebas yaitu $\left(X_{1}\right)$ kualitas system, $\left(X_{2}\right)$ kualitas informasi, $\left(X_{3}\right)$ penggunaan, dan $\left(X_{4}\right)$ kepuasan pemakai berpengaruh secara signifikan terhadap variabel $(Y)$ kinerja karyawan.

Pengujian model regresi secara parsial digunakan untuk mengetahui apakah masing-masing variabel independen pembentuk model regresi secara individu memiliki pengaruh yang signifikan terhadap variabel dependen. Untuk menguji pengaruh tersebut, digunakan uji t, yakni dengan membandingkan nilai thitung dengan tabel, atau nilai signifikansi dengan $\alpha 5 \%$. Berdasarkan tabel 5. di atas, didapatkan hasil sebagai berikut :

1. Variabel $\left(X_{1}\right)$ kualitas sistem memiliki statistik uji t sebesar 0.322 dengan signifikansi sebesar 0.749. nilai statistik uji thitung tersebut lebih kecil dari tabel $(0.322<2.012)$ dan nilai siginifikan t yang lebih besar dari $\alpha(0.05)$. pengujian ini menunjukkan bahwa $H_{0}$ diterima sehingga dapat disimpulkan bahwa variabel $X_{1}$ berpengaruh secara tidak signifikan terhadap variabel $Y$. Atau dapat dikatakan bahawa variabel $X_{1}$ (kualitas sistem) berpengaruh positif dan tidak signifikan terhadap variabel $Y$ (kinerja karyawan). 
2. Variabel $\left(X_{2}\right)$ kualitas informasi memiliki statistik uji t sebesar 1.008 dengan signifikansi sebesar 0.319. Nilai statistik uji thitung tersebut lebih kecil dari ttabel $(1.008<2.012)$ dan nilai signifikansi t yang lebih besar dari a (0.05). Pengujian ini menunjukkan bahwa $\mathrm{H}_{0}$ diterima sehingga disimpulkan bahwa variabel $X_{2}$ berpengaruh secara tidak signifikan terhadap variabel $\mathrm{Y}$. Atau dapat dikatakan bahwa variabel $\mathrm{X}_{2}$ (kualitas informasi) berpengaruh positif dan tidan signifikan terhadap variabel $Y$ (kinerja karyawan).

3. Variabel $\left(X_{3}\right)$ penggunaan memiliki statistik uji t sebesar 1.509 dengan signifikansi sebesar 0.138 . Nilai statistik uji thitung tersebut lebih kecil dari ttabel $(1.509<2.012)$ dan nilai signifikan t yang lebih besari dari $\alpha(0.05)$. Pengujian ini menunjukkan bahwa $\mathrm{H}_{0}$ diterima sehingga dapat dsimpulkan bahwa variabel $X_{3}$ berpengaruh secara tidak signifikan terhadap variabel $\mathrm{Y}$. Atau dapat dikatakan bahwa variabel $\mathrm{X}_{3}$ (penggunaan) berpengaruh positif dan tidak signifikan terhadap variabel $Y$ (kinerja karyawan).

4. Variabel $\left(X_{4}\right)$ kepuasan pemakai memiliki statistik uji t sbesar 0.562 dengan signifikansi sebesar 0.577 . Nilai statistik uji thitung tersebut lebih kecil dari tabel $(0.562<2.012)$ dan nilai signifikan t yang lebih besar dari $\alpha$ (0.05). Pengujian ini menunjukkan bahwa $\mathrm{H}_{0}$ diterima sehingga dapat disimpulkan bahwa variabel $\mathrm{X}_{4}$ berpengaruh secara tidak signifikan terhadap variabel $\mathrm{Y}$. Atau dapat dikatakan bahwa variabel $\mathrm{X}_{4}$ (kepuasan pemakai) berpengaruh positif dan tidak signifikan terhadap variabel $Y$ (Kinerja Karyawan).

Besarnya kontribusi dari variabel independen secara simultan terhadap variabel dependen, berdasarkan hasil perhitungan pada tabel di atas dengan nilai koefisien determinasi (Rsquare) sebesar 0.278. Hasil tersebut menjelaskan sumbangan atau kontribusi dari variabel-variabel bebas (X1) kualitas system, (X2) kualitas informasi, (X3) penggunaan, dan (X4) yang disertakan dalam persamaan regresi terhadap variabel (Y) kinerja karyawan adalah sebesar $27.8 \%$, sedangkan $72.2 \%$ lainnya disumbangkan oleh variabel lainnya yang tidak dimasukkan ke dalam persamaan ini.

\section{PEMBAHASAN}

Berdasarkan hasil analisis data diperoleh kesimpulan bahwa pengaruh efektifitas Sistem Informasi Kampus (Sisfokampus) berpengaruh secara signifikan terhadap kinerja karyawan. Hal tersebut memperlihatkan bahwa penerapan Sisfokampus telah dilaksanakan dilakukan dengan penuh kesungguhan. Dalam hal ini pimpinan telah melaksanakan penerapan Sisfokampus sebagai suatu sistem yang menyediakan fasilitas kepada pengelola organisasi dalam bentuk data maupun informasi yang berkaitan dengan pelaksanaan tugas para karyawan dalam melaksanakan pekerjaannya. Dengan demikian variabel Sistem Informasi Manajemen/Sisfokampus merupakan sarana yang memberikan dukungan kepada para karyawan bagi peningkatan kinerja karyawan di Universitas Islam Malang. 
Secara parsial (masing-masing) faktor-faktor sistem informasi manajemen yang terdiri dari kualitas sistem, kualitas informasi, penggunaan dan kepuasan pemakai berpengaruh positif dan tidak signifikan terhadap peningkatan kinerja karyawan di Universitas Islam Malang.

\section{SIMPULAN DAN SARAN}

Hasil penelitian menunjukkan bahwa (1) Secara simultan (bersamasama) bahwa efektivitas SIM/Sisfokampus telah berpengaruh secara signifikan terhadap peningkatan kinerja karyawan di Universitas Islam Malang, dalam hal ini SIM/Sisfokampus sangat penting untuk meningkatkan kinerja karyawan dalam memecahkan masalah dalam berbagai hal, (2) Secara parsial (masing-masing) faktor-faktor sistem informasi manajemen yang terdiri dari kualitas sistem, kualitas informasi, penggunaan dan kepuasan pemakai berpengaruh positif dan tidak signifikan terhadap peningkatan kinerja karyawan di Universitas Islam Malang, (3) Menurut peneliti banyaknya kendala yang ada pada pengoperasian Sisfokampus ini, dilihat dari hasil penelitian yang menyatakan bahwa tidak semua variabel mendukung upaya peningkatan kinerja karyawan.

Berikut beberapa hasil prosentase atas variabel dari Sisfokampus : (a) Kualitas sistem $50 \%$ setuju atas keakurasian dan $53.84 \%$ tidak setuju dengan kemudahan penggunaan, dan dalam tahapan kuartil berada pada tahapan menuju sedang, (b) Kualitas informasi $63.46 \%$ setuju atas informasi berguna, 65.39\% setuju atas informasi relevan, 36.54\% tidak setuju atas kecepatan informasi dan $61.54 \%$ setuju atas konsistensi informasi. Dan dalam tahapan kuartil berada pada tahapan sedang menuju tinggi, (c) Penggunaan 69.23\% setuju atas penggunaan akhir, 36.54\% setuju atas keinginan sendiri, $44.23 \%$ setuju atas kesadaran diri dan $44.23 \%$ setuju tentang silaturahmi, dan dalam tahapan kuartil berada pada interval sedang menuju tinggi, (d) Kepuasan pemakai $32.70 \%$ netral dan tidak setuju atas kepuasan fungsi dan $59.61 \%$ setuju atas kepuasan informasi, dan dalam tahapan kuartil berada pada interval sedang menuju tinggi.

\section{DAFTAR PUSTAKA}

Mangkunegara, Anwar Prabu, 2006, Perencanaan dan Pengembangan Manajemen Sumber Daya Manusia, Pen. PT Refika Aditama.

Amri, Fachriza dkk, 2013,Analisis Implementasi Sistem ERP (Enterprise Resource Planning) Studi pada PT. Jepe Press Media Utama Surabaya, Jurnal Administrasi Bisnis (JAB) Vol.2 No.2.

Mangkunegara, Anwar Prabu, 2000. Manajemen Sumber Daya Perusahaan. Cetakan Ke-2.Bandung : PT. Remaja Rosda Karya.

C. Laudon, Kenneth \& P. Laudon, Jane, 2005, Sistem Informasi Manajemen Mengelola Perusahaan Digital, Edisi 8, Yogyakarta : Andi Offset.. 
Ghozali, Imam, 2009, Aplikasi Analisis Multivariate dengan Program SPSS, Universitas Diponegoro, Semarang.

Izumi, Nadia. 2010. "Pengaruh Efektivitas Penggunaan dan KepercayaanTerhadapTeknologi Sistem Informasi Akuntansi Terhadap Kinerja AuditorInternal". Skripsi. Universitas Islam Negeri Syarif Hidayatullah

Jogiyanto. 2010. Analisis dan Desain, Sistem Informasi: Pendekatan Terstruktur Teori dan Praktik Aplikasi Bisnis. Yogyakarta: Andi.

Kurnadi, Engkun, (2016), Pengaruh Efektivitas dan Kepercayaan terhadap Kinerja Individu atas Penggunaan Teknologi Sistem Informasi Akuntansi pada Karyawan Perumda BPR Majalengka, Jurnal Ilmiah Manajemen \& Akuntansi, Vol.3 No.1, Januari-Juni.

Machfudz, Masyhuri, 2014, Metodologi Penelitian Ekonomi, Malang : Genius Media.

Malayu S.P Hasibuan. 2005. Manajemen Sumber Daya Manusia. Edisi Revisi, Cetakan ke-7. Jakarta : PT. Bumi Aksara.

Mc. Leod, Raymond. \& Schell, George, P. 2008.Sistem Informasi Manajemen, Edisi 10. Jakarta : Salemba Empat.

Mc Leod, Raymon Jr \& George P. Schell, 2009, Management Information Systems Sistem Infomasi Manajemen, Jakarta : Salemba Empat.

Nazir, Mohammad, 2011, Metode Penelitian, Jakarta : Ghalia Indonesia.

O'Brien dan Marakas, 2010, Management System Information, McGraw Hill, New York.

Rusjiana, Jimmy, (2016), Pengaruh Sistem Informasi SDM Terhadap Kinerja Karyawan di PT. Rabbani Bandung, Vol.10, No.1, Juni : 21 29.

Sanjaya, Imam dan Awangga Febian S.A, 2011, Pengukuran Kesuksesan Sistem Informasi Manajemen Frekuensi (SIMF) dengan Model Delone dan McLean, Buletin Pos dan Telekomunikasi, Vo.9 No.4 Desember 2011.

Subchan, Nur dkk, Mengukur Efektivitas Sistem Informasi dan Mengetahui Kesuksesan Portal Akademik (SIAM) On-line(Studi Kasus Terhadap Pengguna di Program Pendidikan Vokasi Universitas Brawijaya), Jurnal Profit, Vol.6 No.2.

Supriyanto, Achmad Sani \& Masyhuri Machfudz, 2010, Metodologi Riset Manajemen Sumberdaya Manusia, Malang : UIN-Maliki Press.

Widodo, Tri Wahyu dkk.Pengaruh Aplikasi Sistem Informasi Manajemen (SIM) Terhadap Kinerja Karyawan(Studi Kasus Pada Usaha Kecil Menengah Bidang Usaha Warnet Di Kota Malang).Jurnal Profit Volume 7 No.1. 